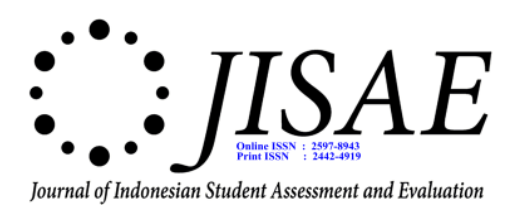

\title{
EFFECTIVE MANAGEMENT CLASS CONCEPT (Case Study: Student Behavior Problematics)
}

\author{
Bambang Afriadi \\ Universitas Islam Syekh-Yusuf \\ afriadi.bambang@yahoo.co.id
}

ABSTRACT

The effectiveness of the learning process is part of good classroom management. But be aware that every individual in the class (student) does not have a homogeneous but heterogeneous character. Implementation of classroom management will encounter various inhibiting factors. Reviews These barriers can come from teachers Themselves, from students, the family environment, and or because of the facilities. The condition of teaching and learning will be sustained while teachers during the process of concentration can maintain student learning and student behavior. Therefore, management in the class Becomes important to be Discussed, and found the solution. In writing this article using research literature from various sources related to this topic related to the subject. Then theoretical research to support this search,

Keywords: Class Management, Student Behavior Problems in Classroom Management

\section{INTRODUCTION}

Education is an important thing for everyone. Education can change a person toward a better change. Through the learning process, the student's character was formed in order to produce changes better than before both in behavior, attitudes and so forth. The learning process in this case is the learning that takes place in the classroom. Through the learning process materials delivered to students in order to achieve the needs of students get a lesson in school.

During the learning process, there are interactions that take place in it. Between teachers and students is very important to establish a harmonious interaction so that the subject matter is able to be conveyed to the students well. According to the terms Gillin Gillin and interaction is social contact and communication (Dany Haryanto \& Edwi Nugrohadi, 2011: 215), Then social contactbe the first element in the interaction. Social interactions that occur in the process of learning can take place when there is social contact and communication between teachers and students and vice versa.

Learning is a combination that includes elements arrayed human, material, facilities, equipment and procedures that interact to achieve the objectives of the study (OEmar Hamalik, 2010: 57).Learning is an integral element of eventually establishing a human activity in terms of teaching and learning. Based on the essence, humans are a major component in moving and directing the learning process. Learning involves elements of human consisting of teachers and students and supported by learning tools such as books, blackboards, reference sources of information such as newspapers, audio and video. Learning as part of classroom management can be supported by increasingly sophisticated technologies such as 
classrooms, equipment, audio-visual, computers also include the procedural aspects and the timetable and method of delivery of information, practice, study, exams, and so forth.

Classroom management has been broadly defined as the act of a teacher is required to create an environment that supports and facilitate learning both academic and social-emotional. Learning procedure can also be considered by the class management. Procedure class structure of the environment, encourage appropriate behavior and reduce the occurrence of inappropriate behaviors necessary for effective classroom management. Components of effective classroom management is important in several ways to handle it. For example, with a focus on prevention rather than reactive procedure establish a positive classroom environment where teachers focus on students behave discipline. Then need to be designed to create an effective learning environment. The main components are: (1) set the class;

Efektifitas learning process is part of a good classroom management. But be aware of each individual in the class (students) do not have a homogeneous but heterogeneous character. With different backgrounds in which students interact with their environment. Where a student's behavior is a manifestation of the results she interacts. There are some behaviors that can impair optimal conditions and situations such as making noise, do not pay attention and and seeking attention. Such behavior arises from students and sometimes teachers, where teachers are less able to properly optimize the management of the class. So that the conditions and the situation is not going well class is a learning process to get results from it is not reached. From this background came the questions in this paper include: (1) What is a classroom management ?, (2) What are the behaviors that undermine the teaching and learning climate ?, (3) What type of classroom management problems? (4) How does the handling of classroom management problems?.

\section{METHODS}

The method of writing this article is the research library using a variety of resources related to this topic. The review of books, literature, records, and reports have to do with the problem is solved. Next is conducting studies related to theories related to the research topic. In search of a theory, researchers will gather as much information from related literature and arranged regularly and used in research.

\section{a Class management}

\section{RESULTS}

Classroom management and teaching management are two different activities which are closely connected, but can and should be distinguished from each other for different purpose. Management of teaching covers all activities which are directly intended to achieve the specific goals of teaching (determining the entry behavior of learners, preparing lesson plans, providing information, asking questions, value and so on), then the class management refers to activities that create and maintain the conditions optimal for learning (coaching "report cards", termination behavior of learners who distract the classroom, reward for 
timely completion of tasks by setting norms productive group, etc. (Ahmad Rohani, 2004: 123).

Teachers as managers of learning, the teacher plays in creating a learning climate that allows students to learn comfortably. Through good classroom management classroom teachers can keep remains conducive to the learning process.

MenuIvor K. devais rut, one that is often overlooked is the tendency to forget that the essence of learning is learning instead of teaching students and teachers. In conjunction with a learning management there are two kinds of activities to do, which is managing the learning resources and carrying out a role as a source of learning itself. As a manager, a teacher has four general functions, namely (Wina Sanjaya, 2006: 24-25):

a. Planning learning goals

b. Organizing various learning resources to realize learning goals

c. Leading, which includes motivating, and stimulating students

d. Keep an eye on everything, whether it is functioning properly or not in order to achieve goals.

While the teachers' classroom management is an effort to create the conditions that are expected to be effective if: first, a precisely known factors that can support the creation of favorable conditions in the teaching-learning process, both known problems are expected and usually arise and can damage teaching and learning climate, thirdly, mastered a variety of approaches to classroom management in mind also when and where an approach to the problem of use.

Effective classroom management is necessary for all teachers. Classroom management involves all aspects of what is happening in the classroom during the lesson being taught. Not only class management includes how teachers provide guidance, but also how students interact with teachers and with others in the class. Classroom management include elements focused on creating a comfortable learning environment peaceful, organized, interesting, and respect for teachers and students.

So that learning produces changes in behavior signikan the learning process should be designed such that it becomes active learning, innovative, creative, effective, and fun. The task of the teacher in this context there was a facilitator who creates for himself the condition, as well as providing infrastructure support, for the establishment of good classroom management and appropriate.

Classroom management strategies need to be planned and in line with the curriculum. It is important to prioritize the curriculum for classroom management. A management plan is a class where clear rules are established, developed the class norm, hope was expressed, and the consequences implemented. Classroom management plan does not not have to be long, complex, or complicated. If the teacher creates too many rules would feel overwhelmed by the students' classroom management. Look for rules that include behavior that can disrupt your learning and student engagement. Creating a classroom management plan should be short. 
Intended to organize an effective learning process with proper time management.

Classroom management plan, also referred to as contracts (regulation) classroom management, teacher contracts are made with students focused on providing their needs in the classroom and a commitment to help students learn without disruption. After the class rules or norms are developed, implemented in class contract then the contract should be followed at all times and therefore require teacher facilitator (prefect) to control the students and themselves accountable at all times. Here is a basic right of students and rules for behavior in the classroom.

a. Basic rights of students

a) All students have the right to be treated with respect.

b) All teachers have the right to be treated with respect.

c) Everyone has the right to feel safe in the teaching and learning environment.

d) Everyone must show a sense of memili and maintain school facilities.

b. Rules for behavior in class

a) Respect each other at all times.

b) Maintain contact when communicating with others or when someone teaches a teacher or classmates speak out in an opinion.

c) When working in groups, say "please" and "Thank you"; praise each other and use politeness.

d) Only one person speaks at a time when the learning process takes place.

\section{b Types of Behavior that Interfere with the Climate of Teaching and Learning}

Tewas previously described teachers' classroom management is the skill of creating and maintaining an optimal learning conditions and restore it when things happen that can disrupt the learning atmosphere. There are several types of behavior that can disrupt the learning climate as described below.

a. Tidak attention

Tidak presence or lack of attention to the students of the subject matter being discussed is one that could interfere with the students' behavior and learning climate. Such behavior is usually indicated by specific actions, such as talking while the teacher is explaining or doing other activities that are not related to the subject matter as found there are some students who inadvertently draw faces teacher was teaching. Such events was the beginning of the teaching and learning climate that is not conducive. The behavior demonstrated by the student comes from a lack of student motivation, which can dodorong by:

a) Students assume not essential to the subject matter being discussed

b) Students feel have had the ability and understanding of the subject matter being discussed

c) Students feel bored or do not fit the pattern of the applied teaching teachers

d) Students looked at the teacher did not master the lesson material that is being presented

86 JISAE. Volume 4 Number 2 September 2018. Copyright @ Ikacana Publisher | ISSN: 2442-4919 | E-ISSN 2597-8934 
If students either them individually and collectively have feelings like that, it is certain that students will be seriously reduced the subject matter

b. Disruptive behavior

Offending behavior can be done by students individually or by groups of students. This behavior is usually indicated by the symptoms mimic behavior like speech or phrase deliberately teacher, say the word "Uuuh" when there are students who ask questions or express opinions, provide the questions should not be asked, memcemooh other students, do gerakan- physical movements that are disturbing to other students and so forth. If left unchecked these behaviors, it will cause an unpleasant atmosphere. Offending behavior can arise from several factors, including:

a) The psychological condition of students, for example, want to be noticed

b) Students have experienced treatment that do not impose on the teachers, and did not realize he had such a feeling of revenge

\section{Type Classroom Management Problems}

There are two types of classroom management issues, namely the individual and nature groups, among others(http://charierfuadah.blogspot.co.id/2013/12/beberapa-masalah-pengelolaankelas.html (Accessed: 30/01/2016 17:01 AM)):

a. Maone of which is the Individual. Classification of individual problems is based on the basic assumption that human behavior that lead to the achievement of a goal. If an individual fails to develop a sense of belonging and sense of himself worthy, he will behave distorted.

a) Attention getting behaviors (attention-seeking behavior patterns). A student who failed to find the position itself appropriately in an atmosphere of mutual acceptance of social relations usually (actively or passively) behave seek other people's attention. Search the destructive behavior of active attention can be found in children who like to show off, droll (poke), making a scene, showing delinquency, continuously ask questions; in short, artisan fuss. Destructive behavior passive attention seeker can be found in children who are lazy or children who continue to ask for help from others

b) Power seeking behaviors (patterns of behavior shows the strength / power). The same behavior with attention seeking power destructive, but deeper. Active power-seekers who like approach, to lie, to show their disagreement, do not want to do are ordered others and displayed openly disobedient attitude. Passive power-seekers who looked at children very tastefully laziness so do not do anything at all. These children are very forgetful, stubborn, and passively showing non-compliance.

c) Revenge-seeking behaviors (behavioral patterns indicate revenge). Students who avenge frustration very deep and does not realize that he was actually looking for success with the hurting others. Malignancy, physical assaults (scratching, biting, kicking) to fellow students, staff or employers, or to 
animals often do these children. Such children will feel pain if defeated, and they are not good players (eg in a game). Children who love this avenging usually prefers to act actively rather than passively. Children avenger active children often known as a fierce and cruel, being passive is known as the children were sullen and disobedient (like opposes).

d) Helplessness (show incompetence). Students who demonstrate an inability basically feel deeply inadequate trying to find something that pleases (ie ownership) are being surrendered to the challenges confronting; The students even assume that there is just in front of the continuous failures. Feelings of hopelessness and helplessness again this is usually followed by behavior retired or retiring. The inability attitude is always in the passive voice.

b. Maone is group. Problem The group, known as the seven issues in relation to the management group class:

a) Class less cohesive (familiar), for reasons of gender, ethnicity, socioeconomic level, and so on.

b) Lack of inability to follow the rules of the group. As deviations from the norms of behavior that has been agreed in advance.

c) Negative reactions to his fellow group members.

d) Reception classes (groups) or deviant behavior.

e) Activities of members or groups that deviate from the conditions set, stop doing activities or just mimic the activities of people (members of) the other alone.

f) Inanimation, do not want to work, and aggressive behavior or protests.

g) Inability to adapt to environmental changes

\section{ANALISIS}

\section{A. analysis Albert Bandura Control System Behavior}

Learning is a change in behavior as a function of experience. Tercangkup changes therein affective, motor, and cognitive generated other causes, Albert Bandura explains the behavior management system that is as berukut (Mulyani Sumantri and Nana Syaodih, 2008: 1:36):

1, stimulus Control

Many human behavior that appears under the direct control of the events of the external stimulus. Reflexive activities such as sneezing, breathing, wink, controlled by an external stimulus. Many of the human behavior that occurs as a conditioned controlled.

2, outcome Control

Many human behaviors are performed is determined to achieve results. When people work for fame, happiness and friendship, it can be said that the 
behavior is controlled by the result to be achieved

3, Syimbolic Control

One more important thing about human behavior is considered in certain circumstances the behavior is controlled by rangasangan from outside or results will be achieved. These behaviors according to Bandura under the control of the symbolic. The behavior can be directed by the formulation of the words of the desired behavior, or it can be imagined diarahkahkan by anticipation of the results to be achieved. Thus most of our behavior is controlled symbolically by an external stimulus by the results expected.

Control system behavior in classroom management by teachers can be seen as follows:

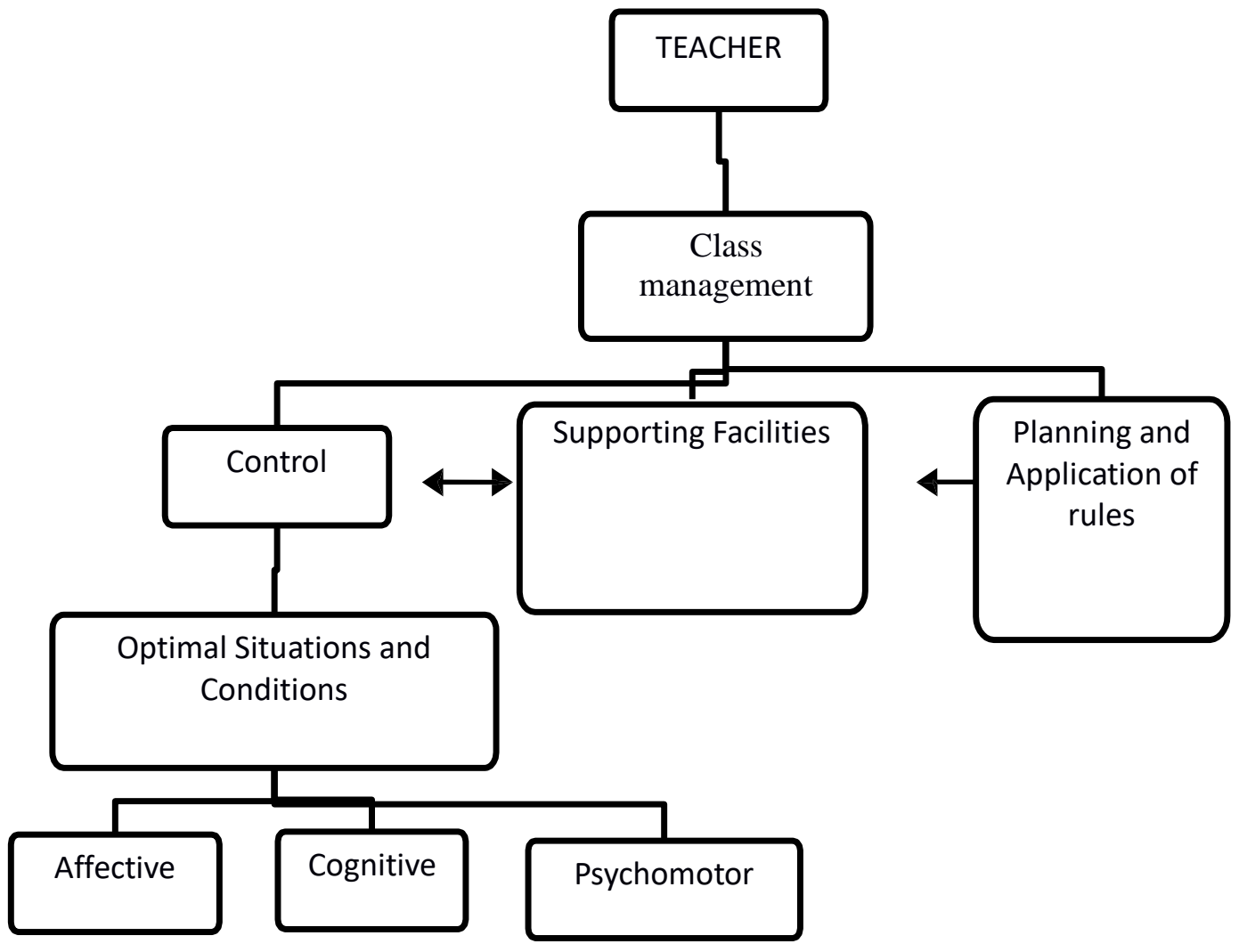




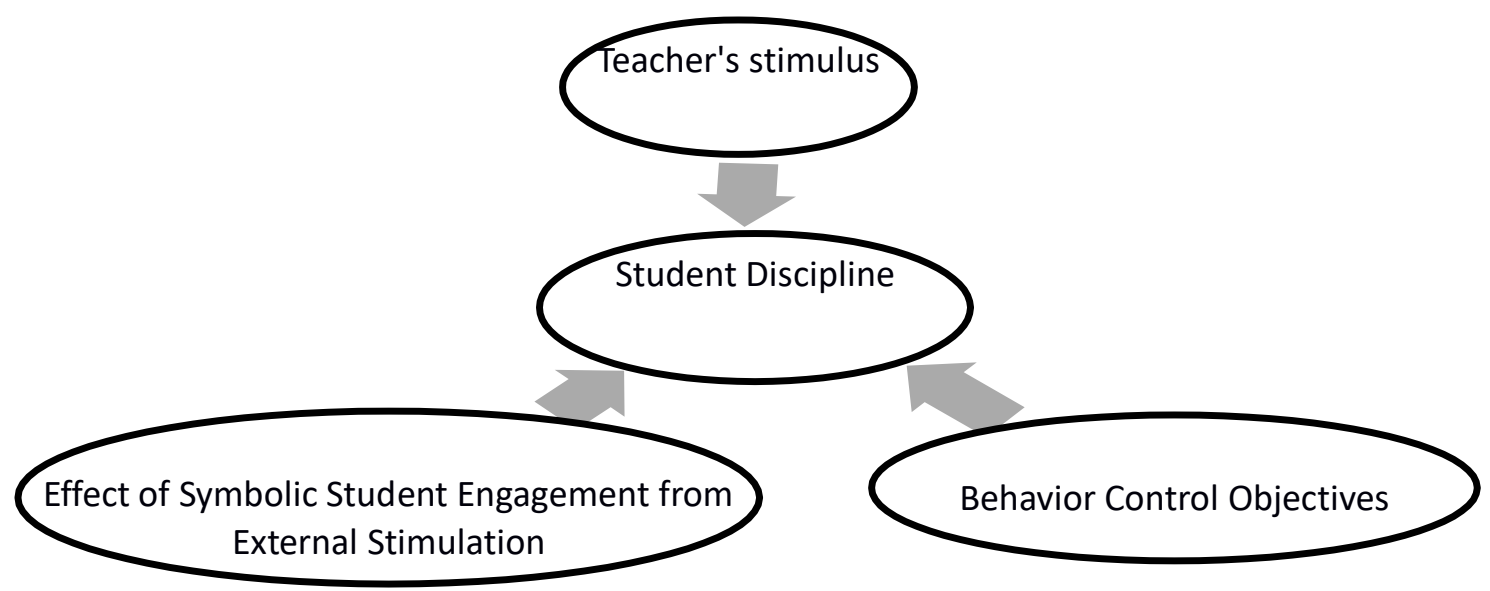

Source: Analysis Writer

Albert Bandura explains "behavior control system to determine the effect of the environment, the role of reaction, learning outcomes through stimulus response and learning outcomes are achieved". First, many individuals are conditioned behavior as it appears under the direct control of the events of the external stimulus. Teachers have an important role to condition the good students in the learning process as a form of classroom management. Class rules to students is conditioned to be disciplined by the teacher as a stimulus factor. Through arrangements in which there are consequences to the actions of a student's behavior will change stimulus which include growths affective, motor and cognitive skills resulting from activities in the classroom.

Second, human behavior carried out is determined to achieve results. In the classroom students learn subjects with the aim of having extensive knowledge of the learning process. More than that students will compete to get academic achievements and he will get praise, happiness, and friendship so that students will continue to try to maintain their achievements. In class, praise, happiness, and friendship are not only derived from academic achievement. Discipline behavior can also obtain this. So that it can be said that the behavior is controlled from the results achieved. Therefore the management of the class must have a basic goal that stimulates students to achieve results, such as there is a category of disciplined, neat, active, respectful students and so on to trigger optimal classroom conditions.

Third, individual behavior is controlled by external stimuli and results achieved. The influence according to Bandura is in symbolic influence. Engagement in learning experiences is a very important influence on learning activities. So that behavior in this case is symbolically controlled by external stimuli from the expected results. When students are expected to be able to absorb discipline with a sense of happiness, happiness will produce positive emotions.

\section{B. Analysis of Obstacles in Classroom Management}

In the implementation of classroom management will encounter a variety of inhibiting factors. Such constraints could come from the teachers themselves, from learners, family environment or for facilities. 
a. factors teacher

Already mentioned above that the teacher can be an inhibiting factor in implementing the creation of a favorable atmosphere in the learning process. Factors that come from teachers can be things below.

a) Tipe teacher leadership

Tipe teacher leadership (manage the learning process) authoritarian and less democratic will foster a positive attitude or aggressive learners. Both attitudes of learners is a source of classroom management issues.

b) Monotonous teaching-learning format

Format monotonous learning will lead to boredom for students. Teaching and learning formats that do not vary can cause learners get bored., Frustrated / disappointed, and this will be a source of violations of discipline.

c) the teacher's personality

A teacher who successfully prosecuted for being warm, fair, objective and flexible so that nurtured the emotional atmosphere of fun in the learning process. An attitude which is contrary to the personality will cause problems in classroom management

d) science teacher

Terbatasnya teacher's knowledge of management issues and management approaches, both theoretical and practical experience. Discuss this issue with colleagues will help in improving classroom management skills in the learning process.

e) Teachers' understanding of learners

Terbatasnya chance teachers to understand the behavior of the learner and his background could be due to a lack of effort the teacher to deliberately understand learners and background, perhaps because they do not know how or because the teaching load of teachers outside the limits reasonable for teaching in various schools so teachers come to school solely for teaching.

b. Factors learners

Another factor that may act as barriers in classroom management is a factor of learners. Learners in the class can be considered as an individual in a small community that is class and school. They should know their rights as part of a whole community in addition they also have to know the obligations and the requirement to respect the rights of others and classmates.

Learners should be aware that if they interfere with his friend who was studying means no obligations as a member of the class society and do not respect the rights of other learners to gain maximum benefit from teaching and learning. Mindless lack of learners in fulfilling the duties and rights as a member of a class or a school can be a major factor penyeban classroom management problems.

Habituation well at school in the form of school discipline that is 
approved and accepted jointly by the school and students (with full awareness) will bring learners orderly towards finesse.

c. family factors

Tingkah behavior of learners in the classroom is a reflection of family circumstances. The attitude of authoritarian parents will be reflected in the behavior of learners who agrasif or apathetic. In the classroom learners are often found no intruder and noisier maker. They usually come from families that are not intact or chaotic.

Bad habits such as family environment undisciplined, undisciplined, excessive or unduly constrained freedom will constitute the background that led to a breach of discipline learners class. It is clear that if the demands in the classroom or school much different from the conditions of family life will constitute a separate hardship for participants didikuntuk adjust. One adjustment learners to a classroom situation will be a management problem. This is where lies the importance of a balanced working relationship between the school and home (parents) so that there is harmony between the situations and demands in the classroom.

d. factors facilities

Factors inhibiting the facility is classroom management. These factors include:

a) Classes that the number of learners much harder to maintain. For example, the number of students in a class in high school, which reached an average of 50 learners and at colleges that sometimes reached about 100 learners is a separate issue in management.

b) Classrooms, which is small compared to the number of learners and the needs of learners to move around in the classroom is another obstacle for management. Similarly, the amount of room that kuran compared with the number of classes and the number of special rooms needed such as laboratories, auditorium, art room, drawing room, oleahraga space, and so require the handling of its own

c) The availability of tools, less the number of books or tools that do not correspond to the number of learners who need would cause problems in classroom management.

\section{Techniques for Avoiding Disruptive Behaviors}

To avoid behaviors that can interfere, then the following techniques can be used in class management:

a. Creating optimal learning conditions

Creating and maintaining optimal learning conditions relates to the ability of teachers to take the initiative in controlling teaching and learning activities to be different in conducive conditions so that student attention is centered on the 
subject matter.

b. Show responsiveness

Showing responsiveness to various behaviors that appear in the classroom, both supporting behaviors such as responsiveness to student attention, student enthusiasm, high student motivation, and so forth. This response is directed so that the teacher's presence in the classroom is truly felt by students.

c. Focus

The condition of teaching and learning will be maintained when during the process the teacher can maintain the concentration of student learning. the technique that we can use to maintain student attention is to focus student attention continuously. Focusing can be done by:

a) Provide visual illustrations, for example by diverting views from an activity to another activity without breaking the contact's view of either the group or the individual students.

b) Give verbal comments through fresh sentences without leaving the context of the subject matter being discussed.

c) Provide clear instructions and goals

Students will learn with full attention when understanding the goals that must be achieved and understand what must be done. There is often a lack of concentration due to incomprehension of the direction and goals that must be achieved.

d. Give rebuke and reinforcement

Reprimand is needed as an effort to modify behavior. Some things that must be considered in admonishing include:

a) Reprimand is directed at students who really disrupt the condition of the class with deviant behavior.

b) Reprimand is done verbally by avoiding rough warnings or insulting or mocking tendencies.

It is recommended that reinforcement be done to students who provide a positive response by giving praise or appreciation both verbally or reasonable comments and through soothing and pleasant cues

\section{Conclusion}

In the implementation of classroom management will encounter a variety of inhibiting factors. Such constraints could come from the teachers themselves, from learners, family environment or for facilities. Such factors affecting classroom management, among others, teachers themselves, from learners, family environment or for facilities. Because that business can be done in classroom management is a factor that should always be considered in dealing with classroom management.

In the process of teaching and learning sustained frequent disturbances, for example students perform behaviors that can interfere with the continuous and repetitive. Climate control learning intended as efforts to improve teaching and 
learning conditions. If teachers have felt it difficult to create a good learning climate because of the disruption ganggunan- unruly, then the teacher can work with a counselor or perhaps the principal.

\section{REFERENCE}

Bluestein, Jane (2013). Manajemen kelas. PT Indeks.

Hamalik, Oemar (2010). Kurikulum dan Pembelajaran. Jakarta: Bumi Aksara.

Haryanto, Dany dan Nugrohadi, Edwi (2011). Pengantar Sosiologi Dasar. Jakarta: PT Prestasi Pustakarya.

Hernawan Herry Asep, dkk (2008). Pengembangan Kurikulum dan Pembelajaran. Jakarta: Universitas Terbuka.

Hidayat, Rakhmat (2014). Sosiologi Pendidikan Emile Durkheim. Jakarta: Rajawali Pers.

http://charierfuadah.blogspot.co.id/2013/12/beberapa-masalah-pengelolaankelas.html (Diakses 30/01/2016 Pukul 17:01)

Rohani, Ahmad (2004). Pengelolaan Pengajaran. Jakarta: PT Rineka Cipta.

Sanjaya, Wina (2006). Strategi Pembelajaran Berorientasi Standar Proses Pendidikan. Jakarta: Kencana.

Sumantri, Mulyani dan Syaodih (2008). Perkembangan Peserta Didik. Jakarta: Universitas Terbuka.

Sunarto dan Agung, Hartono (2006). Perkembangan Peserta Didik. Jakarta: PT Asdi Mahasatya.

Suryabrata, Sumandi (2008). Psikologi Pendidikan. Jakarta: PT Grasindo.

Syah, Muhibbin (2010). Psikologi Pendidikan. Bandung: PT Remaja

Rosdakarya, edisi ke 15. 